\title{
ANALISIS ASPEK PEMBENTUK BUDAYA K3 DENGAN KEPATUHAN PENGGUNAAN APD PADA PEKERJA PRODUKSI RESIN DI SIDOARJO
}

\author{
Gregorius Timotius Brito \\ Departemen Keselamatan dan Kesehatan Kerja \\ Fakultas Kesehatan Masyarakat Universitas Airlangga \\ E-mail: Gregtimo@ymail.com
}

\begin{abstract}
The Ministry of Republic Indonesia launched in 2015 as the national safety culture that every industrial sector was required to implement the safety culture as well. One of the effort to create safety culture in the companies with cultivating the behavior for using personal protection equipment at work. Cooper an expert of safety management explained there were three elements forming safety culture, psychological, behavior, and organization and situation aspect. The main purpose was to analyze the relationship between psychological aspect of workers and organization and a situation aspect with the behavior for using PPE. This is an observational analytic study with cross sectional approach. Data were analyzed with univariate and bivariate. Sample of this research were 25 workers from 32 population that gets by simple random sampling method. Data were collected by questionnaire and observation then analyze in descriptive and use cross tabulating and correlation spearmen test to obtain relationship between variables. The result showed that most of the workers (56\%) have low behavior on PPE usage. There almost all workers have a good motivation and clarified that availability and training about PPE was fair. There were significant correlation between motivation and training with complience of using PPE. Higly recommendation for company to increase the motivation for workers by apply a reward system.
\end{abstract}

Keywords: safety culture, behaviour, Personal Protection Equipment

\section{ABSTRAK}

Pemerintah Republik Indonesia mencanangkan tahun 2015 sebagai tahun berbudaya K3 di mana setiap sektor industri diwajibkan untuk menerapkan budaya K3 yang baik. Upaya untuk menciptakan safety culture di lingkungan perusahaan yaitu dengan membudayakan perilaku penggunaan APD di tempat kerja. Cooper seorang ahli manajemen K3 menyatakan terdapat 3 elemen pembentuk safety culture yaitu aspek psiklogis pekerja, aspek perilaku, dan aspek organisasi dan situasi. Penelitian bertujuan untuk menganalisis hubungan antara aspek psikologis pekerja dan aspek organisasi dan situasi dengan perilaku penggunaan APD. Studi dalam penelitian ini menggunakan teknik observasional analitik dengan menggunakan pendekatan cross sectional. Sampel penelitian menggunakan teknik simple random sampling dan terpilih sebanyak 25 responden dari 32 pekerja. Data dihimpun melalui kuesioner dan observasi perilaku yang kemudian dianalisa secara univariat dan bivariat. Hasil penelitian ini menunjukkan $56 \%$ pekerja memiliki perilaku tidak baik dalam pemakaian APD. Mayoritas pekerja memiliki motivasi yang baik dan menyatakan ketersediaan APD telah memadai serta pelatihan penggunaan APD baik. Motivasi dan pelatihan APD memiliki hubungan dengan kepatuhan penggunaan APD. Rekomendasi yang dapat diberikan bagi perusahaan adalah meningkatkan motivasi pekerja dengan memberikan insentif kepada pekerja yang selalu menggunakan APD.

Kata kunci: budaya K3, perilaku, Alat Pelindung Diri

\section{PENDAHULUAN}

Perkembangan bidang industrial semakin berkembang pesat, terutama pada bidang industri manufaktur. Industri manufaktur sendiri dalam perkembangannya juga sudah mengalami kemajuan yang signifikan hal ini ditandai dengan meningkatnya permintaan pasar domestik, terutama untuk plastik, logam, makanan, manufaktur cat, dan suku cadang otomotif telah tumbuh sebesar 6,4\% di tahun 2013 (World Bank, 2013).
Pesatnya pertumbuhan dan perkembangan industri manufaktur dapat dipastikan semakin banyak juga masalah yang berpotensi muncul. Beberapa masalah yang berpotensi timbul tersebut dari kegiatan industri manufaktur pembuatan cat adalah masalah kesehatan dan keselamatan

Salah satu bahan dasar pembuatan cat adalah resin. Setiap pekerja di industri pembuatan resin memiliki risiko yang sama dengan industri kimia yang lain. Pada proses produksi resin sendiri 
memiliki risiko bahaya yang tinggi seperti yang terdapat pada proses. Faktor fisik yang berpotensi terjadinya hazard adalah kebisingan yang ditimbulkan oleh mesin produksi yang melebihi NAB serta paparan suhu ekstrem akibat tidak adanya ventilasi yang cukup.

Proses produksi pada pembuatan resin juga memiliki potensi bahaya kesehatan yang berpotensi timbul antara lain berasal dari proses pencampuran dan pemasakan bahan baku yang terdiri dari $\mathrm{NH}_{3}, \mathrm{H}_{2} \mathrm{CO}$ (Formaldehid), $\mathrm{C}_{3} \mathrm{H}_{5} \mathrm{NO}$ (Akrilamid), $\mathrm{C}_{2} \mathrm{H}_{5} \mathrm{OH}$ (Etanol), $\mathrm{C}_{7} \mathrm{H}_{8}$ (Toluene) yang di mana seluruh bahan tersebut merupakan bahan berbahaya yang apabila masuk dalam tubuh dapat mengakibatkan kerusakan organ dan sistem saraf dan apabila terpercik kulit juga dapat menyebabkan iritasi pada kulit (Susyanto, 2012).

Resin atau binder merupakan komponen utama dalam pembuatan cat. Resin berfungsi merekatkan berbagai komponen yang ada dan melekatkan keseluruhan bahan pada permukaan suatu bahan. Resin sendiri adalah polymer di mana pada temperature ruang bentuknya cair, bersifat lengket dan kental (Susyanto, 2012). Proses produksi pada pembuatan resin umumnya mengandung risiko bahaya yang sama pada industri manufaktur pada umumnya yang dapat mengakibatkan kecelakaan kerja dan berujung pada penyakit akibat kerja dan kematian.

Potensi bahaya keselamatan kerja dalam industri resin dapat berupa bahaya keselamatan dan kesehatan. Rata-rata kecelakaan yang terjadi di pembuatan resin diakibatkan oleh kecerobohan dan kesalahpahaman antar karyawan. Salah satu contohnya adalah tumpahan dari bahan kimia yang dapat mengenai anggota tubuh pekerja. Terdapat pula faktor fisik yang merupakan bahaya kesehatan di area pembuatan resinya itu kebisingan yang dihasilkan mesin generator, getaran ketika pengoperasian forklift, dan temperatur ekstrem pada tabung reaktor dan boiler. Faktor kimia yang bersifat toxic juga dapat berperan dalam menimbulkan bahaya di industri resin.

Kecelakaan sendiri dapat diartikan sebagai suatu kejadian yang tidak diinginkan dan datang secara tidak terduga yang dapat merugikan manusia, perusahaan, serta lingkungan. Kecelakaan kerja sendiri yang dimaksud adalah kecelakaan yang berhubungan dengan pekerjaan di perusahaan (Suma'mur, 1996).

Pentingnya dilakukan usaha-usaha untuk melindungi pekerja dalam menjalankan pekerjaannya telah ada payung hukumnya dan mendapat perhatian dari pemerintah dengan dikeluarkannya UndangUndang Keselamatan Kerja No. 1 Tahun 1970. Undang-Undang tersebut mengatur setiap kegiatan produksi di perusahaan secara aman agar terhindar dari bahaya yang berpotensi timbul di lingkungan kerja.

Data untuk kecelakaan kerja pada bidang industri manufaktur pembuatan cat untuk tingkat Provinsi Jawa Timur sendiri tidak mudah ditemukan, hal ini disebabkan data kecelakaan kerja termasuk data rahasia internal perusahaan yang tidak dapat dipublikasikan diakses secara bebas oleh pihak lain. Namun apabila melihat tren kecelakaan kerja secara nasional dalam 3 tahun terakhir dan disimpulkan bahwa angka kejadian kecelakaan kerja mengalami kenaikan.

Data dihimpun dari laporan di kemenakertrans yang dikutip oleh Rosidi (2011), di mana menunjukkan bahwa angka kecelakaan kerja pada tahun 2009 terdapat 96.314 kasus kecelakaan kerja. Angka tersebut meningkat pada tahun 2010 yaitu sebanyak 98.711 kasus dan 99.491 kasus kecelakaan di tahun 2011.

Upaya untuk meminimalisir kejadian kecelakaan kerja di industri apabila tidak berjalan dengan baik maka dipastikan lingkungan kerja di industri dapat menjadi ancaman bagi keselamatan pekerja. Terlebih di tahun 2015 dicanangkan oleh pemerintah sebagai 'Tahun Budaya K3' dimana setiap sektor industri khususnya industri manufaktur harus sudah siap dalam menerapkan sistem K3 yang baik dan benar.

Mengingat pula di tahun 2015 akan menghadapi pasar bebas ASEAN yang menuntut setiap industri untuk lebih memiliki daya saing dan kompetensi dalam menerapkan sistem K3. Hal utama yang dapat dilakukan yaitu dengan membina setiap pekerja untuk dapat membudayakan keselamatan dan kesehatan kerja sebagai kebutuhan yang harus dipenuhi di lingkungan kerja. Budaya keselamatan mempersyaratkan agar semua kewajiban para pekerja yang berkaitan dengan keselamatan harus dilaksanakan secara benar, seksama, dan penuh rasa tanggung jawab (Yusri, 2011).

Menurut INSAG (IAEA, 1991) budaya keselamatan merupakan gabungan dari karakteristik dan sikap dalam organisasi dan individu serta merupakan integrasi dari perilaku, sikap, persepsi yang outputnya berupa performansi yang nantinya dapat menggerakkan organisasi.

Budaya keselamatan yang masih rendah ditandai dengan masih rendahnya kepatuhan penggunaan 
APD dalam setiap melakukan pekerjaan yang berisiko tinggi. Pengoperasian mesin produksi, pembuatan bahan baku, dan pengangkutan material produksi yang di mana pada setiap kegiatannya memiliki risiko yang berbeda yang dapat memicu timbulnya bahaya keselamatan dan kesehatan.

Pengendalian bahaya menurut Ladow Joseph (2000) yang dikutip dalam Linggarsari (2008), terdiri dari empat aspek yaitu substitusi, rekayasa engineering, pengendalian perilaku manusia yang dibagi lagi menjadi pengendalian administratif serta pengendalian praktek kerja. Pengendalian praktek kerja lebih menekankan pada pola-pola perilaku individu. Sedangkan pengendalian administratif menekankan pada manajemen untuk mengendalikan pola perilaku di lingkungan dan organisasi.

Membentuk perilaku aman khususnya dalam perilaku penggunaan APD dalam diri pekerja sangat relevan dengan konsep yang dikemukakan oleh Cooper (2000), yang menyatakan bahwa terdapat 3 elemen pembentuk budaya K3 yaitu aspek psikologis pada diri pekerja yang terdiri dari tingkat pengetahuan, harapan, dan motivasi. Elemen yang kedua adalah aspek perilaku pekerja dan aspek organisasi dan situasi.

Terdapat faktor-faktor lainnya yang dapat mempengaruhi perilaku penggunaan APD oleh pekerja berdasarkan teori perilaku Lawrence Green (1980) yang dimuat dalam Notoatmodjo (2003), yaitu faktor predisposisi yang meliputi tingkat pengetahuan, persepsi individu, tingkat motivasi, sikap, dan harapan.

Faktor kedua yaitu enabling adalah faktor pemungkin seperti sarana dan prasarana yang tersedia, dan faktor terakhir adalah reinforcing yang terdiri dari kebijakan atau regulasi yang berlaku, pengawasan, dan dukungan dari stakeholder yang terkait.

Penelitian ini bertujuan untuk Menganalisis hubungan antara aspek psikologis serta aspek organisasi dan situasi pembentuk budaya $\mathrm{K} 3$ dengan perilaku penggunaan Alat Pelindung Diri pada tenaga kerja di produksi resin di Sidoarjo.

\section{METODE}

Penelitian ini bersifat analitik yang bertujuan untuk mengetahui hubungan sebab akibat antara dua variabel yaitu dependen dan variabel bebas secara observasional tanpa memberikan perlakuan atau interaksi terhadap responden penelitian. Ditinjau dari waktu pengambilan data dan rancangannya, penelitian ini termasuk penelitian cross sectional atau potong lintang. Menurut Notoatmodjo (2012), dalam penelitian cross sectional, variabel independen yang terjadi pada objek penelitian diukur atau dikumpulkan secara simultan (satu waktu).

Analisis yang digunakan dalam penelitian bersifat analitikal yaitu untuk mencari hubungan antara variabel independen dengan dependen yang dianalisa secara bivariat untuk mengetahui analisis statistik secara deskriptif melalui frekuensi pada tiap variabel dan univariat untuk mengetahui hubungan statistik antar variabel dependen dengan independen.

Responden dalam penelitian ini adalah seluruh pekerja di produksi resin baik pekerja kontrak maupun pekerja tetap yang berjumlah 32 pekerja yang ditentukan menggunakan rumus simple random sampling seperti yang dikemukakan oleh Walpole (1995). Sampel terpilih sebanyak 25 pekerja yang dipilih secara acak dengan menggunakan data nama seluruh pekerja di produksi resin Sidoarjo yang kemudian diolah menggunakan rumus.

Penelitian ini berlangsung selama 5 bulan dilaksanakan pada bulan februari hingga juli 2015. Komponen dalam penelitian ini meliputi perilaku penggunaan APD, aspek psikologis yaitu motivasi pekerja dalam penggunaan APD, aspek organisasi dan situasi yang terdiri dari ketersediaan APD dan pelatihan terkait APD. Komponen penelitian dihimpun melalui kuesioner, kegiatan observasi dan wawancara dengan pihak HSE atau Health Safety Environment, serta menggunakan data sekunder yakni berupa literatur dan dokumen internal.

Tabel 1. Interpretasi Kuat Hubungan

\begin{tabular}{cc}
\hline Interval Koefisien & Tingkat Hubungan \\
\hline $0,80-1,00$ & Sangat kuat \\
$0,60-0,79$ & Kuat \\
$0,40-0,59$ & Cukup kuat \\
$0,20-0,39$ & Lemah \\
$0,00-0,19$ & Sangat lemah \\
\hline
\end{tabular}

Sumber: Riduwan 2013

Data yang berhasil dihimpun selanjutnya diolah secara univariat dan bivariat. Analisis univariat digunakan untuk mendiskripsikan masing-masing variabel yang diteliti. Hasil analisa data univariat disajikan dalam bentuk distribusi frekuensi disertai narasi. Analisis bivariat digunakan untuk melihat hubungan antara variabel independen dengan variabel dependen. Hasil data bivariat disajikan dalam bentuk tabulasi silang. 
Uji analisis data bivariat yang digunakan adalah spearman's rho dengan $\alpha=0,05$. Sedangkan untuk mengetahui kuat hubungan dilakukan uji kuat hubungan melalui uji spearman's rho correlation, sehingga diperoleh nilai koefisien korelasi. Kategori tingkat hubungan dapat dilihat pada Tabel 1 di atas.

\section{HASIL}

\section{Perilaku Penggunaan APD}

Perilaku kepatuhan penggunaan APD di produksi resin Sidoarjo mayoritas dapat dikategorikan tidak baik yaitu dengan tidak menggunakan APD secara konsisten dan lengkap. Data tersebut diperoleh melalui kegiatan observasi perilaku penggunaan APD di produksi resin Sidoarjo yang dilakukan secara berkala.

Observasi dilakukan menggunakan lembar observasi dan dalam pelaksanaannya observasi dibantu juga oleh pihak supervisor. Penggunaan APD di produksi resin merupakan suatu kewajiban yang telah diatur dalam regulasi perusahaan dan bagi pekerja yang tidak menggunakan akan dikenai sanksi. APD yang wajib digunakan meliputi 4 jenis yaitu helm keselamatan, masker, sepatu keselamatan, sarung tangan.

Tabel 2. Distribusi Perilaku Penggunaan APD di Produksi Resin di Sidoarjo

\begin{tabular}{lcc}
\hline \multicolumn{1}{c}{ Perilaku } & Frekuensi & Persentase (\%) \\
\hline Baik & 11 & 44 \\
Tidak baik & 14 & 56 \\
\hline Jumlah & 25 & 100 \\
\hline
\end{tabular}

Pada Tabel 2 diketahui dari 25 pekerja yang menjadi responden penelitian di produksi resin terdapat 14 orang pekerja (56\%) memiliki perilaku tidak baik dalam pemakaian APD ketika bekerja, sedangkan sebanyak 11 pekerja (44\%) memiliki perilaku baik dalam penggunaan APD selama melakukan pekerjaan.

\section{Motivasi}

Berdasarkan data yang diperoleh dari kuesioner untuk mengukur tingkat motivasi pekerja terhadap pemakaian APD, mayoritas pekerja memiliki tingkat motivasi yang baik dalam penggunaan APD di lingkungan kerja yaitu sebanyak 19 pekerja (76\%), sementara pekerja yang memiliki motivasi tidak baik dalam penggunaan APD hanya sebanyak 6 pekerja (24\%) dari total 25 pekerja di produksi resin.
Tabel 3. Tabulasi Silang Antara Motivasi dengan Penggunaan APD pada Pekerja di Produksi Resin di Sidoarjo.

\begin{tabular}{lrrrrrr}
\hline \multirow{2}{*}{ Motivasi } & \multicolumn{3}{c}{ Perilaku penggunaan APD } \\
\cline { 2 - 7 } & \multicolumn{2}{c}{ Baik } & \multicolumn{3}{c}{ Tidak baik } & \multicolumn{2}{c}{ Total } \\
\cline { 2 - 7 } & $\boldsymbol{\Sigma}$ & $\boldsymbol{\Sigma}$ & $\mathbf{\%}$ & $\boldsymbol{\Sigma}$ & $\mathbf{\%}$ \\
\hline Baik & 11 & 57,99 & 8 & 42,11 & 19 & 100 \\
Tidak baik & 0 & 0 & 6 & 100 & 6 & 100 \\
\hline Total & 11 & 44 & 14 & 56 & 25 & 100 \\
\hline Sig. & \multicolumn{7}{c}{0,011} \\
\hline Koefisien korelasi & 0,498 \\
\hline
\end{tabular}

Hasil tabulasi silang antara tingkat motivasi dengan perilaku penggunaan APD, diketahui bahwa pekerja yang memiliki motivasi baik sebagian besar $(57,99 \%)$ memiliki perilaku yang baik dalam penggunaan APD dan pekerja yang memiliki motivasi tidak baik seluruhnya $(100 \%)$ memiliki perilaku tidak baik dalam penggunaan APD.

Pada Tabel 3 diketahui terdapat hubungan yang signifikan antara tingkat motivasi dengan penggunaan APD sedangkan untuk melihat kuat hubungan antar variabel, diperoleh nilai dari koefisien korelasi sebesar 0,498 yang artinya hubungan cukup kuat antara tingkat motivasi pekerja dengan perilaku pemakaian APD pada pekerja di unit produksi resin Sidoarjo.

Hubungan yang terjadi bersifat positif atau searah yang berarti semakin baik motivasi pekerja semakin baik pula perilaku dalam penggunaan APD ketika bekerja atau semakin tidak baik tingkat motivasi pekerja semakin tidak baik pula perilaku dalam penggunaan APD.

\section{Ketersediaan APD}

Penyediaan APD untuk pekerja di unit produksi resin di Sidoarjo dikategorikan menjadi 2 yaitu memadai dan kurang memadai. APD yang disediakan oleh pihak perusahaan untuk unit produksi resin sesuai dengan risiko bahayanya berdasarkan hasil observasi dan wawancara dengan pihak HSE meliputi helm keselamatan, masker, sepatu keselamatan, sarung tangan.

Penyediaan APD pada produksi resin telah disesuaikan dengan risiko bahaya yang ada. Bahaya di lingkungan kerja diketahui melalui kegiatan risk assessment atau penilaian risiko bahaya yang rutin dilakukan oleh pihak HSE perusahaan pada setiap bulannya. Penilaian risiko yang dilakukan menggunakan teknik Job Safety Analyze yaitu dengan menganalisis potensi bahaya setiap kegiatan produksi yang dilakukan. 
Tabel 4. Tabulasi Silang Antara Ketersediaan APD dengan Penggunaan APD pada Pekerja di Produksi Resin di Sidoarjo.

\begin{tabular}{lrrrrrr}
\hline \multirow{2}{*}{\begin{tabular}{c} 
Ketersediaan \\
\multicolumn{1}{c}{ APD }
\end{tabular}} & \multicolumn{6}{c}{ Perilaku penggunaan APD } \\
\cline { 2 - 7 } & $\boldsymbol{\Sigma}$ & $\mathbf{\%}$ & $\boldsymbol{\Sigma}$ & $\mathbf{\%}$ & \multicolumn{1}{c}{$\boldsymbol{\Sigma}$} & $\mathbf{\%}$ \\
\hline Memadai & 11 & 50 & 11 & 50 & 22 & 100 \\
Kurang memadai & 0 & 0 & 3 & 100 & 3 & 100 \\
\hline Total & 14 & 56 & 11 & 44 & 25 & 100 \\
\hline Sig. & 0,110 & & & \\
\hline Koefisien korelasi & 0,327 \\
\hline
\end{tabular}

Hasil penelitian menunjukkan mayoritas pekerja menyatakan bahwa APD yang tersedia di produksi resin sudah memadai baik dari segi kualitas, kuantitas, dan akses APD yaitu sebanyak 22 pekerja (88\%), sedangkan sebanyak 3 orang pekerja (12\%) menyatakan bahwa APD di produksi resin di Sidoarjo kurang memadai. Menurut hasil wawancara dengan pihak HSE perusahaan jumlah APD di unit produksi resin sendiri telah disesuaikan dengan jumlah pekerja yaitu sebanyak 32 pekerja.

Hasil penelitian membuktikan bahwa pekerja yang berperilaku baik dan menyatakan bahwa APD yang tersedia telah memadai ketersediaannya sebanyak 11 orang pekerja (50\%), sama dengan pekerja yang berperilaku baik dan menyatakan bahwa ketersediaan APD kurang memadai yaitu sebanyak 11 pekerja (50\%). Pekerja yang menyatakan ketersediaan APD kurang memadai seluruhnya (100\%) memiliki perilaku tidak baik dalam penggunaan APD.

Pada Tabel 4 tingkat signifikansi diketahui bernilai 0,110 dan dikatakan tidak terdapat hubungan yang signifikan antara ketersediaan APD dengan perilaku pemakaian APD karena nilai p $(0,110)$ lebih besar dari nilai $\alpha(0,05)$. Kuat hubungan antar variabel dapat dilihat pada nilai koefisien korelasi yaitu sebesar 0,327 yang berarti hubungan lemah antara ketersediaan dengan perilaku kepatuhan pemakaian APD pada pekerja di produksi resin.

\section{Pelatihan APD}

Berdasarkan data yang diperoleh melalui wawancara dengan pihak HSE perusahaan, diketahui dilakukan pelatihan dan safetybriefing tentang pekerjaan yang akan dilakukan, keselamatan dalam bekerja, dan tentang cara penggunaan dan pemeliharaan APD yang dilakukan rutin setiap pagi sebelum memulai pekerjaan.

Menurut data hasil dari kuesioner, dapat diketahui terdapat 5 pekerja (20\%) yang menyatakan bahwa pelatihan yang didapatkan kurang memadai dan sebanyak 20 pekerja $(80 \%)$ di produksi resin Sidoarjo menyatakan pelatihan yang diberikan sudah memadai.

Pelatihan terkait penggunaan APD yang dimaksudkan adalah pelatihan mengenai cara pemakaian APD yang baik serta memelihara APD yang benar. Pelatihan diperuntukkan bagi seluruh pekerja di salah satu produksi resin di Sidoarjo baik pekerja kontrak maupun tetap dan bersifat wajib diikuti. Pelatihan sendiri dilakukan rutin setiap pagi sebelum memulai pekerjaan oleh pihak HSE perusahaan.

Tabel 5. Tabulasi Silang antara Pelatihan terkait APD dengan Penggunaan APD pada Pekerja di Produksi Resin di Sidoarjo.

\begin{tabular}{lrrrrrr}
\hline & \multicolumn{7}{c}{ Perilaku penggunaan APD } \\
\cline { 2 - 7 } Pelatihan APD & \multicolumn{2}{c}{ Baik } & \multicolumn{3}{c}{ Tidak baik } & \multicolumn{2}{c}{ Total } \\
\cline { 2 - 7 } & $\boldsymbol{\Sigma}$ & $\mathbf{\%}$ & $\boldsymbol{\Sigma}$ & $\mathbf{\%}$ & $\boldsymbol{\Sigma}$ & $\mathbf{\%}$ \\
\hline Memadai & 11 & 55 & 9 & 45 & 20 & 100 \\
Kurang memadai & 0 & 0 & 5 & 100 & 5 & 100 \\
\hline Total & 11 & 44 & 14 & 56 & 25 & 100 \\
\hline Sig. & 0,026 \\
\hline Koefisien korelasi & 0,443 \\
\hline
\end{tabular}

Berdasarkan hasil tabulasi silang pada Tabel 5 antara pelatihan terkait APD dengan perilaku kepatuhan pemakaian APD pekerja di unit produksi resin di Sidoarjo diketahui pekerja yang menyatakan bahwa pelatihan sudah memadai sebagian besar $(55 \%)$ memiliki perilaku yang baik dalam penggunaan APD. Pekerja yang menyatakan bahwa pelatihan yang tersedia kurang memadai seluruhnya $(100 \%)$ memiliki perilaku yang tidak baik dalam penggunaan APD.

Berdasarkan uji statistik yang diperoleh menunjukkan terdapat hubungan yang signifikan antara pelatihan APD dengan penggunaan APD pada pekerja. Hubungan yang terjadi cukup kuat antara variabel pelatihan terkait APD dengan perilaku penggunaan APD.Hal ini dapat dilihat dari nilai koefisien korelasi yaitu 0,443 yang berarti hubungan antara variabel dapat dikatakan cukup kuat.

Hubungan yang terjadi bersifat positif atau searah yang menunjukkan semakin pekerja menyatakan pelatihan telah memadai maka perilaku penggunaan APD juga semakin baik atau semakin pekerja menyatakan pelatihan kurang memadai maka perilaku penggunaan APD pada pekerja juga menunjukkan semakin tidak baik pula. 


\section{PEMBAHASAN}

\section{Perilaku penggunaan APD}

Berdasarkan hasil penelitian, sebagian besar pekerja pada produksi di Sidoarjo, yaitu sebanyak $56 \%$ responden memiliki perilaku yang dikategorikan tidak baik dalam kepatuhan menggunakan APD yaitu dengan tidak menggunakan APD secara lengkap sesuai dengan yang diwajibkan di unit produksi resin. Hal ini diperoleh dari hasil pengambilan data yang dilakukan melalui metode observasi menggunakan lembar observasi yang dilakukan selama 4 kali.

Observasi dilakukan secara berkala yaitu sebanyak 4 kali di mana terdiri dari 2 kali pengamatan sebelum istirahat kerja dan 2 kali setelah istirahat kerja. Teknik pengulangan pengamatan bertujuan untuk mengurangi adanya bias serta mampu memahami keadaan secara nyata dan holistik (Hadi, 1987).

Upaya yang telah dilakukan oleh pihak HSE perusahaan dalam hal penanggulangan bahaya di lingkungan kerja antara lain dengan melakukan kegiatan penilaian risiko bahaya dan pengendaliannya. Kegiatan tersebut dilakukan secara berkala pada seluruh unit produksi di perusahaan termasuk pada unit produksi resin.

Kegiatan lain dalam penanggulangan bahaya adalah dengan mengadakan safety patrol terhadap perilaku penggunaan APD pada seluruh pekerja. Kegiatan safety patrol dimaksudkan juga untuk mengawasi dan melakukan kontrol pada setiap pekerjaan yang dilakukan oleh pekerja termasuk perilaku bekerja yang baik dan aman.

Penggunaan APD pada pekerja di unit produksi resin di Sidoarjo hanya sebatas untuk mengurangi risiko bahaya yang sewaktu-waktu dapat terjadi pada pekerja. Menurut Tarwaka (2008), agar pekerja dapat terhindar dari risiko bahaya maka perlu upaya dalam hirarki pengendalian bahaya yang meliputi eliminasi, subtitusi, rekayasa teknik, pengendalian administrasi, dan yang terakhir adalah penggunaan APD.

Penggunaan APD merupakan kewajiban pekerja ketika memulai pekerjaannya.APD yang disediakan di produksi resin telah dikondisikan sesuai dengan potensi dan risiko bahaya yang dapat terjadi pada pekerja melalui kegiatan risk assessment and determining control oleh pihak HSE perusahaan. APD yang diwajibkan antara lain helm keselamatan, masker, sepatu keselamatan, sarung tangan.
Hasil pengamatan dan wawancara menunjukkan bahwa APD yang tersedia telah sesuai dengan jumlah pekerja di unit produksi resin dan seluruh APD dalam keadaan baik. Kepatuhan (compliance) sendiri merupakan bentuk perilaku yang tidak hanya dipengaruhi oleh faktor eksternal melainkan juga oleh faktor internal (Geller dalam Ruhyandi \& Evi Candra, 2008).

Berdasarkan hasil pengamatan dan wawancara singkat dengan pekerja, diketahui masih adanya pekerja yang tidak patuh dalam penggunaan APD dikarenakan pekerja masih merasa terlindungi meskipun tidak menggunakan APD. Terdapat juga beberapa pekerja yang baru memakai APD ketika dilakukan safety patrol oleh pihak supervisor dan HSE perusahaan.

Hal ini menunjukkan kepedulian pekerja akan keselamatan dan kesehatan pada saat bekerja masih rendah. Banyak bahaya di lingkungan kerja yang berpotensi muncul dan membahayakan keselamatan dan kesehatan pekerja apabila pekerja sendiri masih belum sadar dengan kondisi tersebut dengan masih berperilaku tidak baik dalam penggunaan APD.

Pihak HSE perusahaan sendiri telah menerapkan sistem punishment bagi pekerja yang tidak menggunakan APD ketika melakukan pekerjaan. Setiap pekerja di produksi resin telah memiliki kartu pelanggaran $\mathrm{K} 3$ dan lingkungan dan kartu tersebut wajib dibawa setiap hari. Kartu tersebut terdiri dari beberapa jenis pelanggaran salah satunya tidak menggunakan APD ketika bekerja.

Apabila ditemukan pekerja yang tidak menggunakan APD akan mendapatkan sanksi yaitu berupa peringatan. Apabila pekerja yang sama melakukan pelanggaran lagi seperti tidak memakai APD, untuk karyawan kontrak akan dikembalikan ke perusahaan outsourching sedangkan untuk karyawan tetap akan dikenakan pemotongan gaji.

Perilaku tidak patuh dalam penggunaan APD merupakan salah satu behavioral hazard yang dipandang sederhana tapi justru berperan besar dalam mayoritas kecelakaan kerja yang diakibatkan dari tindakan tidak aman. Heinrich dalam Suchaida (2013), mengatakan setiap 330 tindakan tidak aman, berpotensi terjadi 29 kecelakaan kecil dan 1 kecelakaan serius serta dapat menyebabkan hilangnya hari kerja. Untuk mengurangi terjadinya tindakan tidak aman, maka perlu dibudayakan safe behavior yang baik dan benar khsusunya dalam perilaku penggunaan APD (Cooper, 2009).

Clarke (2000) dalam Kurniasih dan Renanda Nia Rachmadita (2013), menyatakan bahwa perilaku 
merupakan salah satu komponen budaya organisasi yang outputnya merupakan performansi yang dapat membentuk dan menggerakkan roda organisasi secara berkesinambungan. Budaya organisasi sendiri dapat dikembangkan dan menjadi bagian dari budaya K3.

Mengingat pada Tahun 2015 dicanangkan pemerintah sebagai tahun berbudaya K3 maka pihak produksi resin di Sidoarjo juga melakukan upaya untuk lebih membudayakan penggunaan APD pada pekerja melalui kegiatan promotif dan pengawasan secara berkala demi terciptanya suatu nilai di dalam diri pekerja untuk dapat lebih membudayakan penggunaan APD ketika melakukan pekerjaan.

\section{Motivasi}

Menurut Mangkunegara (2005), motivasi pekerja dapat terbentuk dari sikap pekerja dalam menghadapi situasi kerja di perusahaan. Motivasi juga merupakan energi yang dapat menggerakkan diri pekerja yang terarah dan tertuju untuk mencapai tujuan suatu organisasi.

Dalam hal ini motivasi yang dapat mempengaruhi perilaku pekerja terkait kepatuhan pekerja dalam menggunakan APD saat bekerja. Motivasi yang terdapat dalam diri pekerja sendiri merupakan salah satu aspek psikologis yang dapat mempengaruhi perilaku yang berkaitan dengan K3 khususnya dalam safe behavior yang juga merupakan salah satu aspek dalam pembentuk budaya K3.

Berdasarkan hasil penelitian diketahui pekerja yang memiliki motivasi baik sebagian besar $(57,99 \%)$ memiliki perilaku yang baik dalam penggunaan APD dan pekerja yang memiliki motivasi tidak baik seluruhnya (100\%) memiliki perilaku tidak baik dalam penggunaan APD.

Diperoleh hasil uji statistik menggunakan korelasi spearmen yang menunjukkan terdapat hubungan yang signifikan antara tingkat motivasi dengan perilaku kepatuhan penggunaan APD. Hubungan yang terjadi bersifat positif di mana semakin baik tingkat motivasi pekerja maka perilaku pekerja dalam penggunaan APD semakin baik juga, sebaliknya semakin tidak baik motivasi pekerja maka pekerja juga berperilaku tidak baik dalam penggunaan APD ketika bekerja.

Didapatkan juga nilai koefisien korelasi sebesar 0,498 yang artinya terdapat hubungan cukup kuat kedua variabel tersebut. Hubungan yang terjadi bersifat positif, artinya semakin baik motivasi pekerja maka semakin baik pula perilaku pekerja dalam penggunaan APD.
Hal ini serupa dengan penelitian Sukardjo (2012) dalam Sumarna (2013), bahwa tingkat motivasi pekerja dalam menggunakan APD berhubungan signifikan dengan perilaku penggunaan APD. Hal ini dikarenakan motivasi akan penggunaan APD khususnya dalam pemberian penghargaan untuk pekerja yang selalu menggunakan APD ketika bekerja masih belum berjalan.

Pekerja yang memiliki motivasi tinggi dalam menggunakan APD saat melakukan pekerjaan turut serta melindungi diri dari penyakit maupun kecelakaan kerja yang berpotensi terjadi. Keselamatan merupakan salah satu kebutuhan pekerja yang wajib dipenuhi ketika berada di lingkungan kerja. Apabila kebutuhan yang menjadi tanggung jawab perusahaan tersebut tidak terpenuhi maka pekerja berhak melakukan protes kepada pimpinannya.

Maslow (1984), telah membagi beberapa kebutuhan manusia dalam suatu hierarki kebutuhan dan kebutuhan pekerja akan keselamatan sendiri berada di atas kebutuhan yang paling dasar yaitu kebutuhan fisiologis. Kebutuhan akan rasa aman mencakup kebutuhan akan perlindungan diri dari ancaman, bahaya, serta pertentang baik di lingkungan sosial maupun di lingkungan kerja.

Saran yang dapat diberikan yaitu perusahaan dapat menerapkan sistem reward yaitu dengan memberikan penghargaan berupa insentif kepada pekerja yang selalu menggunakan APD ketika bekerja guna memunculkan motivasi pekerja untuk lebih peduli dengan keselamatan dan kesehatannya salah satunya dengan selalu menggunakan APD pada saat bekerja.

\section{Ketersediaan APD}

Berdasarkan hasil penelitian diketahui $50 \%$ pekerja berperilaku baik dan tidak baik yang berjumlah sama serta menyatakan bahwa ketersediaan APD di unit produksi resin telah memadai. Pekerja yang menyatakan ketersediaan APD kurang memadai seluruhnya (100\%) memiliki perilaku tidak baik dalam penggunaan APD. Hasil uji statistik spearmen menunjukkan tidak terdapat hubungan yang signifikan antara ketersediaan APD dengan perilaku penggunaan APD.

Nilai koefisien korelasi menunjukkan angka 0,327 yang berarti hubungan lemah. Tidak terdapatnya hubungan antara ketersediaan APD menurut pekerja dengan perilaku penggunaan APD telah sejalan dengan penelitian yang dilakukan oleh Ruhyandi dan Evi Candra (2008). Dari penelitian 
ini terdapat 3 pekerja yang menyatakan ketersediaan APD belum mencukupi dan berperilaku tidak baik yang memiliki arti bahwa tidak semua responden menggunakan seluruh APD yang tersedia dan diwajibkan digunakan di unit produksi resin. Berdasarkan hasil observasi terdapat beberapa responden yang hanya menggunakan sepatu dan helm keselamatan.

Faktor penentu atau determinan perilaku penggunaan APD tidak hanya dipengaruhi oleh ketersediaan APD di tempat kerja semata, terdapat beberapa faktor penentu lain baik yang ada dalam diri pekerja maupun tidak. Hal ini dikarenakan mengingat perilaku sendiri merupakan resultan atau perpaduan dari beberapa faktor, baik internal maupun eksternal salah satunya yang berhubungan dengan lingkungan kerja (Shobib, Catur Yuantari dan Massudi, 2013).

Faktor eksternal yang dimaksudkan yaitu segala faktor yang berasal dari lingkungan kerja yang dapat mempengaruhi perilaku pekerja antara lain ketersediaan, kenyamanan dan akses terhadap letak APD. Perusahaan telah menyediakan APD sesuai dengan risiko bahaya yang berpotensi terjadi di produksi resin di Sidoarjo. APD yang dimaksud antara lain helm keselamatan, masker, sepatu keselamatan, sarung tangan.

Berdasarkan hasil wawancara dengan pihak HSE jumlah APD yang disediakan oleh perusahaan telah disesuaikan dengan jumlah pekerja di unit produksi resin. Apabila terdapat pertambahan pekerja di unit produksi resin khususnya pekerja kontrak pihak HSE akan melakukan pendataan ulang guna menyesuaikan jumlah APD dengan jumlah pekerja yang ada di unit produksi resin.

Hal tersebut telah sesuai dengan regulasi yang mengatur tentang keselamatan dan kesehatan di tempat kerja khususnya yang tertuang di Undangundang No. 1 Tahun 1970 pasal 14 butir c yang menyatakan pengurus (pengusaha) diwajibkan untuk mengadakan secara cuma-cuma semua Alat Pelindung Diri yang diwajibkan pada tenaga kerja di bawah pimpinannya. Hal ini juga serupa dengan Peraturan Menteri Tenaga Kerja dan Transmigrasi No.8/MEN/VII/2010 pasal 2 ayat 1 yang mewajibkan setiap pengusaha untuk menyediakan APD bagi pekerja/buruh di tempat kerja.

Penggunaan APD sendiri hanya untuk mengurangi risiko bahaya di lingkungan kerja dan digunakan apabila upaya pengendalian secara teknis dan administrasi tidak dapat melindungi atau memberikan pengendalian yang cukup. Ketersediaan
APD di tempat kerja harus menjadi perhatian penuh dari pihak perusahaan dan manajemen.

\section{Pelatihan APD}

Pelatihan merupakan kegiatan yang didesain untuk membantu meningkatkan akses pekerja untuk mendapatkan pengetahuan, keterampilan dan meningkatkan sikap serta perilaku yang dibutuhkan untuk melaksanakan pekerjaan dengan baik demi tercapainya tujuan organisasi (Atmowidiwiro, 2002 dalam Iqbal, 2014).

Pelatihan yang dimaksud dalam penelitian ini meliputi frekuensi, materi pelatihan, dan pemberi materi. Berdasarkan data yang dihimpun diketahui sebanyak pekerja yang menyatakan bahwa pelatihan sudah memadai sebagian besar $(55 \%)$ memiliki perilaku yang baik dalam penggunaan APD. Pekerja yang menyatakan bahwa pelatihan yang tersedia kurang memadai seluruhnya $(100 \%)$ memiliki perilaku yang tidak baik dalam penggunaan APD.

Hasil uji statistik korelasi spearmen diperoleh nilai signifikansi $p=0,026<\alpha=0,05$ yang berarti terdapat hubungan yang signifikan antara pelatihan dengan perilaku kepatuhan.

Koefisien korelasi menunjukkan angka 0,443 sehingga dapat dikatakan hubungan yang terjadi cukup kuat. Hubungan yang terjadi bersifat positif di mana semakin banyak pekerja menyatakan pelatihan telah memadai dan perilaku dalam penggunaan APD juga semakin baik, sedangkan semakin banyak pekerja yang menyatakan pelatihan kurang memadai semakin tidak baik pekerja dalam berperilaku terhadap pemakaian APD.

Hal sesuai dengan penelitian terdahulu yang dilakukan Ruhyandi dan Evi Candra (2008), yang menyatakan terdapat hubungan antara pelatihan dengan perilaku penggunaan APD. Hal ini dikarenakan masih terdapat beberapa pekerja yang menyatakan bahwa pelatihan yang dilakukan kurang memadai di mana pekerja tersebut mungkin tidak hadir dan tidak mengikuti dengan baik dan benar ketika dilakukan pelatihan terkait APD oleh pihak HSE perusahaan. Akibat dari hal tersebut berdampak pada perilaku pekerja dalam menggunakan APD seperti tidak lengkap dalam pemakaiannya dan tidak selalu menggunakan APD ketika bekerja.

Menurut Maulana (2013), tujuan dari proses pelatihan adalah untuk memperoleh sesuatu yang baru, yang dulu belum ada sekarang menjadi ada, yang belum diketahui menjadi diketahui, dan yang belum mengerti menjadi mengerti. Pelatihan yang dilakukan pada pekerja di produksi resin lebih ke 
arah safety briefing di mana telah terdapat juga beberapa materi pelatihan dalam safety briefing dan dilakukan oleh pihak HSE perusahaan pada pagi hari sebelum seluruh kegiatan produksi dimulai.

Materi meliputi petunjuk keselamatan bekerja, cara bekerja yang aman, dan terkait cara penggunaan APD yang baik dan benar. Pihak HSE perusahaan juga akan melakukan pelatihan ulang terkait penggunaan APD apabila terdapat jenis APD baru. Terdapat juga beberapa media seperti leaflet dan poster yang digunakan sebagai media promosi untuk mengingatkan dan membantu pekerja untuk lebih peduli dengan keselamatan dan kesehatannya.

Akan tetapi, keberadaan media K3 seperti poster dan banner yang bersifat motivatif di lingkungan produksi hanya tersedia 1 buah. Poster dan banner yang bersifat motivatif sendiri merupakan salah satu media pendidikan kesehatan yang dapat berfungsi sebagai saluran untuk menyampaikan pesan khususnya dalam hal penggunaan APD bagi pekerja. Dengan adanya media K3 diharapkan pekerja dapat memperoleh pengetahuan terkait K3 khususnya APD yang lebih baik lagi.

Pengetahuan tersebut nantinya dapat berpengaruh terhadap perilakunya. Dengan adanya media K3 yang terdapat di lingkungan kerja tersebut, dapat membawa akibat terhadap perubahan perilaku pekerja (Notoatmodjo, 2007). Kegiatan safety briefing wajib diikuti oleh pekerja setiap pagi sebelum bekerja. Beberapa pekerja sendiri juga telah rutin mengikuti kegiatan tersebut meskipun juga ada beberapa pekerja yang tidak mengikuti.

Mayoritas pekerja pernah dan selalu mengikuti safety briefing, namun masih terdapat pekerja yang berperilaku tidak baik dalam penggunaan APD selama bekerja. Hal ini membuktikan bahwa safety brieving belum mampu untuk merubah perilaku pekerja dalam hal kepatuhan penggunaan APD. Oleh karena itu, hendaknya perusahaan melakukan tindakan lanjutan dengan melakukan evaluasi terkait materi dan frekuensi pelatihan yang dilakukan.

Upaya lain yang dapat dilakukan perusahaan seperti yang dikemukakan oleh Geller (1942), yaitu melakukan safety training yang berbasis pada teori behavior based safety. Safety training dapat dilakukan dengan menggunakan pendekatan yang berbasis psikologis dan personal di mana prinsip kekeluargaan antar pekerja yang telah terjalin di lingkungan kerja dapat dijadikan salah satu program dalam upaya keselamatan dan kesehatan kerja (Geller, 1942 dalam Kurnia, 2011).

\section{SIMPULAN}

Hasil penelitian menunjukkan bahwa terdapat hubungan yang signifikan antara aspek psikologis yaitu tingkat motivasi pekerja dengan perilaku penggunaan APD ketika bekerja pada pekerja di produksi resin di Sidoarjo. Terdapat hubungan yang signifikan antara aspek organisasi dan situasi yaitu pelatihan terkait APD dengan perilaku penggunaan APD. Tidak terdapat hubungan yang signifikan antara ketersediaan APD dengan perilaku penggunaan APD pada pekerja di produksi resin di Sidoarjo. Pekerja di produksi resin memiliki perilaku yang tidak sebanyak $56 \%$ pekerja dalam penggunaan APD. Perilaku pekerja tersebut ditunjukkan dengan tidak menggunakan APD secara lengkap dan teratur ketika melakukan pekerjaan.

\section{DAFTAR PUSTAKA}

Cooper, D. 2000. Towards a Model of Safety Culture. Applied Behavioural Science. 36, 111-136.

Cooper, D. 2009. Behavioral Safety A Framework for Success. Indiana: BSMS.

Geller, E.S. 1942.The Psychology of Safety Handbook. USA: Lewish Publisher.

IAEA. 1991. Safety culture. Safety Report volume 75. INSAG-4.

Hadi, Sutrisno. 1987. Metodologi Research Jilid 2. Yogyakarta: Andi Offset.

Iqbal, Mochammad. 2014. Gambaran Faktor-faktor Penggunaan Alat Pelindung Diri pada Pekerja di Departemen Metalforming PT. Dirgantara Indonesia Tahun 2014. Skripsi. Jakarta: Universitas Islam Negeri Starif Hidayatullah.

Kurnia, I. Martianti. 2011. Penyusunan Rancangan Program Safety Training yang Berbasis Perilaku Consistency Safety pada Jabatan Operator Gondola Di PT. GHP. Jurnal. Jakarta: Universitas Indonesia.

Kurniasih dan Renanda Nia Rachmadita. 2013. Pengukuran Budaya K3 pada Tingkat Non Manajerial dengan Menggunakan Cooper's Reciprocal Safety Culture Model di PT. X. Jurnal Politeknik Perkapalan Negeri Surabaya. Vol . VIII (No. 2). pp. 83-88.

Linggasari. 2008. Faktor yang Memengaruhi Perilaku terhadap Penggunaan Alat Pelindung Diri di Departemen Engineering PT Indah Kiat Pulp \& Paper TBK Tangerang. Skripsi. Depok: Universitas Indonesia.

Mangkunegara, A. 2005. Evaluasi Kinerja SDM. Bandung: Refika Aditama. 
Maslow, Abraham. 1984. Motivasi dan Kepribadian. Jakarta: Pustaka Binaman Pressindo.

Massora, Gregorius. 2015. Hubungan Faktor Internal (Aspek Psikologis) dan Faktor Eksternal (Aspek Organisasi dan Situasi) dengan Kepatuhan Penggunaan APD. Skripsi. Surabaya: Universitas Airlangga.

Maulana, D.J. Heri. 2013. Promosi Kesehatan. Jakarta: EGC.

Notoatmodjo, Soekidjo. 2003. Pendidikan dan Perilaku Kesehatan. Jakarta: Rineka Cipta.

Notoatmodjo, Soekidjo. 2007. Kesehatan Masyarakat: Ilmu dan Seni. Jakarta: Rineka Cipta.

Notoatmodjo, Soekidjo. 2012. Metodologi Penelitian Kesehatan. Jakarta: Rineka Cipta.

Peraturan. 2010. Permenakertrans No. 8 Tahun 2010 tentang Alat Pelindung Diri. Jakarta: Peraturan Menteri Tenaga Kerja.

Perundangan. 1970. Undang-Undang No. 1 Tahun 1970 tentang Keselamatan Kerja. Jakarta: Perundangan.

Riduwan. 2013. Metode \& Teknik Menyusun Tesis. Bandung: ALFABETA.

Rosidi.2011. "Menakertrans Klaim Kecelakaan Kerja Tahun 2010 Turun".http://economy.okezone. com/read/2011/01/12/320/413040/menakertransklaim-kecelakaan-kerja-2010-turun. (tanggal sitasi: 2 februari 2015,19.00).

Ruhyandi dan Evi Candra. 2008. Faktor-faktor yang Berhubungan dengan Perilaku Kepatuhan Penggunaan APD pada Karyawan Bagian Press Shop PT. ALMASINDO Tahun 2008. Jurnal K3. Vol. 38. pp $29-44$.
Suchaidah, A. 2013. Penerapan Budaya K3 Pada Unit Paper Machine II PT. Kertas Leces (Persero) Probolinggo. Tugas Akhir. Surabaya: Universitas Airlangga.

Suma'mur. 1996. Higene Perusaaan dan Kesehatan Kerja. Jakarta: Gunung Agung.

Sumarna, Furqan Naiem, dan Syamsiar Russem. 2013. Determinan Penggunaan Alat Pelindung Diri pada Karyawan Percetakan di Kota Makassar. Jurnal. Makassar: Universitas Hassanudin.

Susyanto, H. 2012. Resin.http://www.geocities.com/ herisusyanto/Resin.htm (tanggal sitasi: 30 maret 2015, 19.00).

Shobib, Catur Yuantari dan Massudi. 2013. Hubungan Antara Pengetahuan dan Sikap Dengan Praktik Pemakaian

APD pada Petani Pengguna Pestisida di Desa Curut Kecamatan Penawangan Kabupaten Grobogan. Jurnal Keselamatan dan Kesehatan Kerja. http://eprints.dinus.ac.id/7796/(tanggal sitasi: 27 februari 2015, 19.00)

Tarwaka. 2008. Keselamatan dan Kesehatan Kerja. Surakarta: Harapan Press.

Walpole. 1995. Pengantar Statistika. Jakarta: Gramedia Pustaka Utama.

World bank. 2013. Pertumbuhan Industri Mendekati 7 Persen.http://www.kemenperin.go.id/ (tanggal sitasi: 30 Desember 2014, 14.30).

Yusri, H. 2011. Improving Our Safety Culture.Jakarta: PT. Gramedia Pustaka Utama. 